\title{
TAPAK EKOLOGI PULAU LOMBOK NUSA TENGGARA BARAT
}

\author{
Oleh: \\ Baiq Ahda Razula Apriyeni \\ Program Studi Pendidikan Geografi, FKIP, \\ Universitas Hamzanwadi, Lombok Timur \\ nengahda28@gmail.com
}

\begin{abstract}
Abstrak
Salah satu alat yang dapat digunakan dalam pendugaan kebutuhan dan ketersediaan sumberdaya adalah dengan menggunakan pendekatan tapak ekologi. Pendekatan tapak ekologi dapat digunakan untuk menghitung seberapa besar kemampuan suatu wilayah untuk dapat memenuhi segala kebutuhan komponen yang ada dalam sebuah ekosistem. Pentingnya evaluasi tapak ekologi yang ada di Pulau Lombok dapat menjadi suatu masukan untuk dapat mengetahui bagaimana ketersedian biokapasitas yang ada untuk memenuhi kebutuhan penduduk setempat maupun penduduk daerah lain, sehingga dapat menjadi acuan dalam perencanaan pemanfaatan ruang sebagai upaya mewujudkan pembangunan yang berkelanjutan dan diharapkan dapat bermanfaat sebagai alat penunjang keputusan bagi pengambil kebijakan dalam mewujudkan kemandirian pangan berkelanjutan. Penelitian ini bertujuan untuk: Menghitung nilai tapak ekologis Pulau Lombok berdasarkan Global Footprint Network (GFN). Perhitungan tapak ekologi mengasilkan nilai keseimbangan ekologi sebesar 0,01978 gha. Hal ini menunjukkan bahwa secara keseluruhan Pulau Lombok berada pada kategori Wilayah Surplus sumberdaya.
\end{abstract}

Kata kunci: tapak ekologi, biokapasitas, defisit ekologi, surplus sumberdaya

\begin{abstract}
One of the approaches that can be used to estimate the needs and availability of resources is an ecological footprint approach. The ecological footprint approach can be used to estimate the region's ability in fulfilling the needs of the existing components within an ecosystem. The ecological footprint evaluation in Lombok Island is important since it can provide information to know the existing biocapacity availablility in the region to meet the needs of local residents and residents of other regions, so that it may become a reference for performing a spatial use planning as an effort to realize sustainable development and is expected to be useful as a basis for policy makers to make a decision in realizing sustainable food independence. This research aims atestimating the ecological footprint value of Lombok Island based on Global Footprint Network (GFN). The ecological footprint calculation yields an ecological equilibrium value of $0.01978 \mathrm{gha}$. This indicates that the overall Lombok Island belongs to the category of a Surplus Resource Area.
\end{abstract}

Keywords: Ecological footprint, biocapacity, ecological deficit, resources surplus . 


\section{PENDAHULUAN}

Pulau Lombok merupakan salah satu pulau yang terdapat di provinsi Nusa Tenggara Barat, terdiri dari empat kabupaten dan satu kotamadya. Luasnya mencapai lebih kurang $4.738,14 \mathrm{~km}^{2}$. Tingginya pertumbuhan penduduk di Pulau Lombok berbanding terbalik dengan luas wilayah Pulau Lombok yang sempit. Pertumbuhan penduduk di Pulau Lombok tahun 2013 berjumlah 3.228.654 jiwa dan pada tahun 2015 meningkat menjadi 3.352.988 Jiwa (BPS NTB 2015). Diperkirakan pada tahun 2035 jumlah penduduk Pulau Lombok terus meningkat menjadi 4.573 .319 jiwa. Dengan laju pertumbuhan penduduk sebesar 1,56 persen setiap tahunnya, dalam kurun waktu 20 tahun mendatang jumlah penduduknya bertambah sebesar 1.222.331 jiwa.

Peningkatan jumlah penduduk dapat mempengaruhi kebutuhanakan ruang untuk berbagai aktivitas masyarakat serta adanya peningkatan jumlah konsumsi sumberdaya secara berlebihan. Hal ini dapat memicu terjadinya konversi lahan pertanian menjadi lahan non pertanian. Pertambahan jumlah penduduk akan mempengaruhi luas lahanpertanian dan cenderung mengikuti model linier (Munibah et al, 2009). Setiap tahunnya lahan pertanian seperti sawah luasannya semakin berkurang seiring dengan meningkatnya jumlah penduduk dan pesatnya perkembangan ekonomi. Hal ini akan dapat mempengaruhi jumlah produksi padi dimasa yang akan datang. Salah satu dampak konversi lahan yang sering mendapat sorotan masyarakat luas adalah terganggunya ketahanan pangan yang merupakan salah satu tujuan pembangunan nasional (Irawan 2005). Meskipun saat ini Pulau Lombok diperkirakan surplus beras sekitar 155.707 ton dengan jumlah produksi 5.884 .353 ton/hektar dan rata-rata konsumsi beras meningkat sebesar 127,8 kg per kapita per tahun dibandingkan sebelumnya sebesar 122 $\mathrm{kg} / \mathrm{kapita} /$ tahun, namun jika dibarengi dengan tingginya laju konversi setiap tahun dan tidak ada upaya pengendalian maka dapat mengancam keberlanjutan kemandirian pangan di Pulau Lombok.

Berdasarkan perhitungan data yang tersedia, dengan laju konversi sebesar 4,5 persen per tahun diprediksikan hingga tahun 2024 Pulau lombok masih akan mengalami surplus beras namun di tahun 2025 dengan jumlah penduduk 3.916 .758 jiwa akan mengalami defisit sebesar -11.608 ton/kapita/tahun, hingga pada tahun 2035 jumlah penduduk meningkat menjadi 4.575.319 jiwa dan akan mengalami defisit hingga mencapai -168.655 ton/kapita/tahun. Artinya 20 tahun yang akan datang jika laju konversi terus meningkat maka di perkirakan pasokan (supply) sumberdaya yang ada di Pulau Lombok tidak cukup dan bahkan mengalami defisit untuk memenuhi kebutuhan konsumsi sumberdaya penduduknya. Kabupaten/kota yang akan mengalami konversi paling signifikan diantara 5 kabupaten yang ada di Pulau Lombok adalah Kota Mataram, Lombok Barat dan Lombok Tengah. Sedangkan di Kabupaten Lombok Timur dan Lombok Utara masih relatif aman karena didukung juga oleh program cetak sawah baru oleh pemerintah.

Sebagai ekosistem pulau kecil, Pulau Lombok memiliki keanekaragaman hayati yang cukup tinggi, namun juga memiliki resiko lingkungan yang tinggi karena keterbatasan daya dukung lahan yang sempit. Laju pertumbuhan penduduk akan mendorong bertambahnya permintaan konsumsi sumberdaya yang dapat berimplikasi negatif terhadap pemanfaatan 
ruang. Hal ini dapat memicu terjadinya konversi lahan dan alih fungsi lahan pertanian menjadi lahan non pertanian dimana setiap tahunnya lahan pertanian seperti sawah luasannya semakin berkurang seiring dengan meningkatnya jumlah penduduk dan pesatnya perkembangan ekonomi. Hal ini akan dapat mempengaruhi jumlah produksi padi dimasa yang akan datang. Salah satu dampak konversi lahan yang sering mendapat sorotan masyarakat luas adalah terganggunya ketahanan pangan yang merupakan salah satu tujuan pembangunan nasional (Irawan, 2005). Tantangan utama dalam penyediaan sumberdaya saat ini dan dimasa yang akan datang adalah ketersediaan sumber daya lahan yang makin langka (lack of resources), baik luas maupun kualitasnya serta konflik penggunaannya (conflict of interest) (Pasandaran, 2006).

Oleh karena itu pendugaan tentang berbagai kebutuhan penting dilakukan sehingga diharapkan dapat mewujudkan pemanfaatan ruang yang berhasil dan berdaya guna untuk mewujudkan pembangunan berkelanjutan. Alat yang dapat digunakan dalam pendugaan kebutuhan dan ketersediaan sumberdaya adalah pendekatan tapak ekologi atau sering disebut Ecological Footprint. Tapak ekologi suatu pendekatan yang dapat digunakan untuk menghitung seberapa besar daya dukung dan daya tampung yang tersedia untuk memenuhi kebutuhan manusia yang terus bertambah. Tapak ekologi diperhitungkan menggunakan global hektar. Pentingnya evaluasi tapak ekologis yang ada di Pulau Lombok dapat menjadi suatu masukan untuk dapat mengetahui bagaimana ketersedian sumberdaya yang ada untuk memenuhi kebutuhan penduduk setempat maupun penduduk daerah lain, sehingga dapat menjadi acuan dalam perencanaan penggunaan ruang sebagai upaya mewujudkan pembangunan yang berkelanjutan dan diharapkan dapat bermanfaat sebagai alat penunjang keputusan bagi pengambil kebijakan dalam mewujudkan kemandirian pangan berkelanjutan. Penelitian ini bertujuan untuk menghitung nilai tapak ekologis Pulau Lombok melalui pendekatan permintaan (demand) dan pasokan (supply) dan berdasarkan Global Footprint Network.

\section{METODE}

Penelitian ini dilaksanakan di Pulau Lombok. Jenis data yang digunakan dalam penelitian ini berupa jenis data sekunder dan data primer. Data skunder berupa peta administrasi, data statistik Provinsi Nusa Tenggara Barat, profil Pulau Lombok, data tentang luas lahan, dan data lainnya. Sedangkan untuk data primer berupa hasil pengamatan tentang kondisi fisik wilayah di lapangan oleh peneliti. Data Skunder diperoleh dari instansi pemerintah, baik dari BAPPEDA, BPS, Dinas PU, Dinas Pertanian dan Peternakan, Dinas Kehutanan dan Perkebunan, Dinas Penataan Ruang, Perikanan dan Kelautan.

Tapak ekologi menggambarkan kebutuhan barang dan jasa yang diperlukan oleh manusia dari alam yang dicerminkan dalam konsumsi bersih (net consumption) dari produk-produk yang dikategorikan seperti produk pertanian, produk peternakan, produk kehutanan, produk perikanan, keperluan ruang dan lahan, serta konsumsi energi. Untuk perhitungan kuantitatif tapak ekologi yang meliputi perhitungan tapak ekologi dan biokapasitas dari setiap kategori penggunaan lahan digunakan rumus sebagai berikut: 
Menghitung nilai permintaan akan sumberdaya diberbagai penggunaan lahan dapat digunakan rumus hitungan berdasarkan metode yang telah dikembangkan oleh Global Footprint Network (GFN) yaitu:

$E F=P \times Y W \times E q F$

dimana :

$E F$ : Tapak ekologis (gha)

$P \quad:$ Jumlah produksi (ton/ha)

$Y_{W}:$ : Produktifitas lahan di Pulau Lombok (ton/ha)

EqF : Faktor Penyama (Equivalenc Factor)

$B K=A \times Y F \times E q F$

Dimana :

$B K$ : Biokapasitas (gha)

$A$ : Luas Area yang digunakan (ha)

$Y F$ : Faktor Panen(Yield Factor)

EqF : Faktor Penyama(Equivalenc Factor)

Skema struktur perhitungan nilai tapak ekologi di Pulau Lombok dapat dilihat pada Gambar 1.

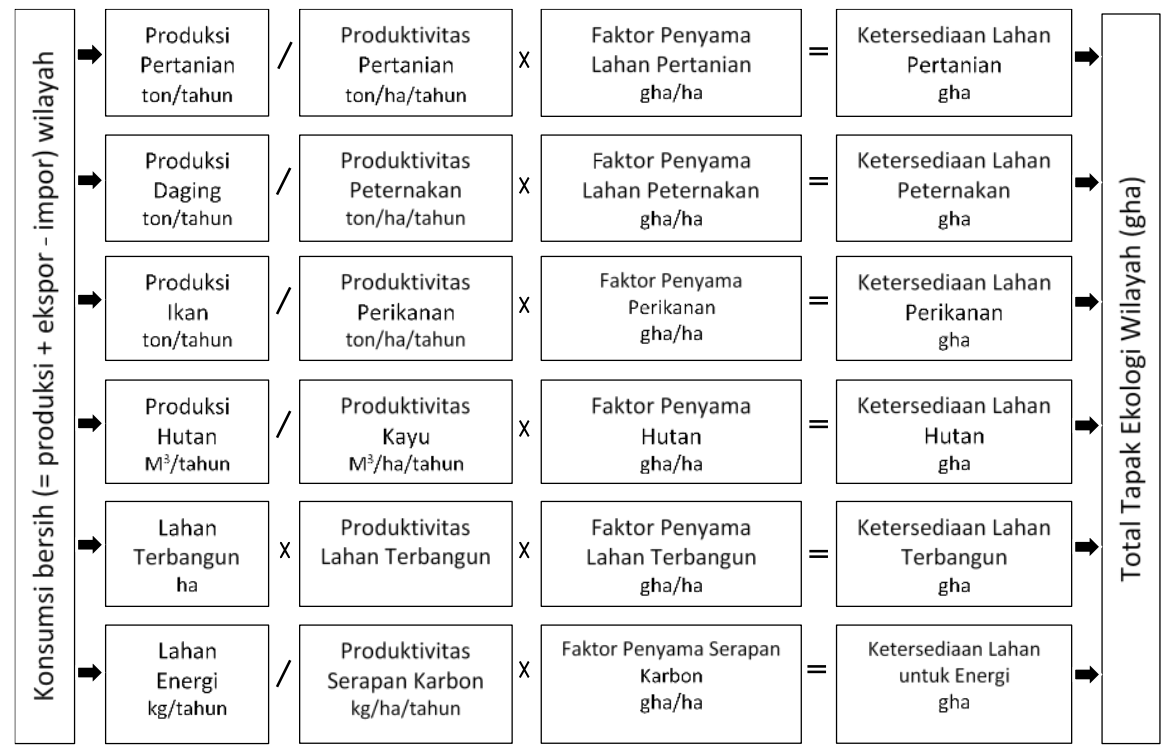

Gambar 1. Stuktur Perhitungan Nilai Tapak Ekologi

Skema struktur perhitungan nilai biokapasitas di Pulau Lombok dapat dilihat pada Gambar 2. 


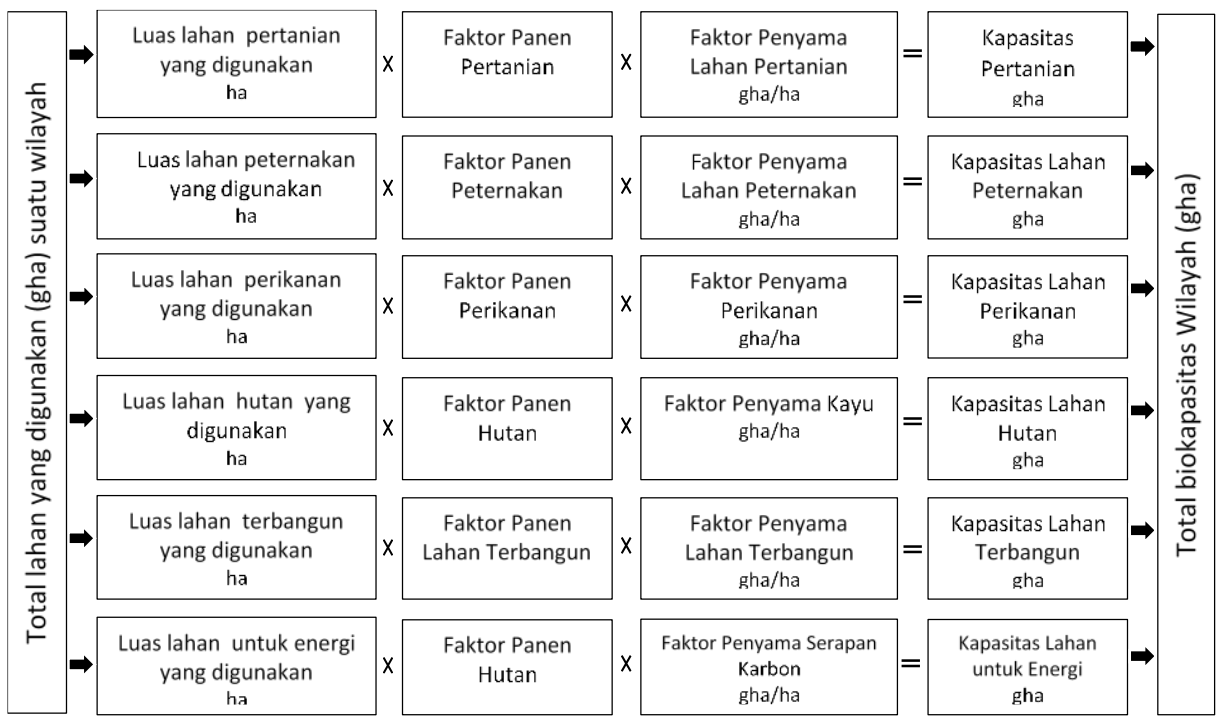

Gambar 2. Stuktur Perhitungan Nilai Biokapasitas

\section{Faktor penyama}

Faktor penyama merupakan faktor yang digunakan untuk mengkombinasikan tapak ekologi dari lahan yang berbeda. Equivalence Factor adalah jumlah hektar global yang terkandung dalam rata-rata hektar lahan pertanian, lahan penumpukan, hutan, padang rumput atau perikanan. Bagian penting dari analisis ecological footprint suatu wilayah atau zona diwakili oleh perhitungan kapasitas biologisnya (biokapasitas) yang memperhitungkan permukaan tanah yang produktif secara ekologis yang terletak didalam wilayah yang diteliti.

Agar ini dapat dikombinasikan maka dibutuhkan koefisien untuk menyamakannya. Dengan kata lain, ini dipakai untuk mengkonversi satuan lokal lahan tertentu menjadi satuan yang universal, yaitu hektar global (gha). Faktor penyama telah ditentukan oleh Global Footprint Network (GFN) untuk 6 (enam) kategori lahan, yaitu: lahan pertanian $(2,1)$, lahan perikanan $(0,4)$, lahan peternakan $(0,5)$, lahan kehutanan $(1,4)$, lahan terbangun $(2,2)$ dan lahan penyerapan karbon/lahan yang diperlukan untuk mengabsorsi $\mathrm{CO}_{2}$ yang bersumber dari bahan bakar fosil (1,4) (Ewing et al. 2010). Adapun nilai Faktor Penyama tiap kategori lahan berdasarkan GFN dapat dilihat pada Tabel 1.

\section{Faktor Panen ( Yield Factor)}

Faktor panen (yield factor) menggambarkan perbandingan antara luasan lahan bioproduktif di suatu wilayah dengan luasan lahan bioproduktif yang sama di wilayah yang lain untuk setiap komoditas yang sama. Faktor ini juga menggambarkan kemampuan suatu populasi untuk menyertakan penguasaan teknologi dan manajemen dalam pengelolaan lahan. Setiap wilayah memiliki faktor panen masing-masing dan dihitung per tahun. 
Tabel 1. Nilai Faktor Penyama dan Faktor Panen berdasarkan GFN

\begin{tabular}{lcc}
\hline Lahan Bioproduktif & $\begin{array}{c}\text { Faktor Penyama } \\
\text { (gha) }\end{array}$ & $\begin{array}{c}\text { Faktor Panen } \\
\text { Lahan Pertanian }\end{array}$ \\
Pertanian Primer & 2,19 & - \\
Pertanian Marginal & 1,19 & 0,98 \\
Lahan Pengembalaan & 0,80 & 2,57 \\
Lahan Kehutanan & 1,48 & 1,81 \\
Lahan Perikanan & 0,36 & 0,82 \\
Lahan Terbangun & 2,19 & 3,39 \\
Lahan Penyerap Karbon & 1,37 & 0,98 \\
\end{tabular}

(Wackernagel dan Rees 2005).

\section{Defisit Ekologis/ Ecological Footprint Deficit (ED)}

Dasar pemikiran analisis pendekatan ini berasal dari kemampuan lingkungan untuk mendukung kehidupan manusia. Untuk mengetahui nilai defisit ekologi dan status tapak ekologis yang ada, maka perlu dilakukan perhitungan defisit ekologis menggunakan rumus:

$$
E \boldsymbol{D}=\boldsymbol{E} \boldsymbol{F}_{\text {Total }}-\boldsymbol{B} \boldsymbol{C}_{\text {Total }}
$$

Dimana:

ED : Defisit ekologis

$E F_{\text {Total }}:$ Permintaan total

$B C_{\text {Total }}$ : Pasokan total

Luasan permintaan (area demanded) bisa lebih besar dari luasan pasokan (area supplied). Jika permintaan suatu ekosistem melebihi kemampuan ekosistem untuk menyediakannya maka bernilai defisit dan sebaliknya jika masih mampu maka dapat dikategorikan bernilai surplus sumberdaya. Nilai defisit ekologi tertera pada Tabel 2.

Tabel 2. Nilai defisit ekologi

\begin{tabular}{llll}
\hline Wilayah Defisit & & \multicolumn{2}{l}{ Wilayah Cadangan atau Seimbang } \\
\hline Sangat Defisit & $(E D>2.0)$ & Wilayah seimbang & $(-0.1<E D \leq 0.1)$ \\
Defisit & $(1.0<E D \leq 2.0)$ & Wilayah cadangan & $(E D \leq-0.1)$ \\
Defisit Sedang & $(0.5<E D \leq 1.0)$ & & \\
Sedikit Defisit & $(0.1<E D \leq 0.5)$ & & \\
\hline
\end{tabular}

Sumber: (Ditjen Penataan Ruang 2010) 


\section{Asumsi Perhitungan:}

Lahan pertanian adalah lahan yang paling bioproduktif dari semua jenis penggunaan lahandan terdiri dari area yang digunakan untuk menghasilkan makanan dan serat untuk dikonsumsi manusia. Untuk mendapatkan nilai tapak ekologi di Pulau Lombok, digunakan data jumlah produksi setiap komoditas yang ada pada lahan pertanian, terdiri dari jenis tanaman pangan dan holtikultura serta tanaman perkebunan. Jumlah produksi yang ada dibagi dengan produktivitas nasional Propinsi NTB pada setiap komoditas kemudian dikalikan dengan faktor penyama untuk menghasilkan nilai dalam satuan hektar global.

Lahan pengembalaan merupakan area yang digunakan untuk memelihara ternak daging dan susu. Dihitung dengan membandingkan seberapa besar jumlah konsumsi daging yang dibutuhkan (sapi, kerbau, kambing) dengan seberapa besar jumlah daging yang mampu diproduksi oleh ternak lahan pengembalaan jika dibandingkan dengan luas lahan untuk pakan ternak yang disediakan ditahun tersebut. Karena hasil dari lahan penggembalaan mewakili jumlah produksi primer atas lahan yang tersedia dalam satu tahun. Nilai Tapak ekologi lahan hutan dihitung berdasarkan jumlah produksi kayu baik kayu bulat maupun kayu bakar yang dikonsumsi oleh masyarakat Pulau Lombok pada tahun tersebut. Perkiraan produktivitas kayu yang berasal sumberdaya hutan dunia menghasilkan nilai rata-rata $0,07 \mathrm{~m}^{3}$ per hektar per tahun.

Lahan perikanan dihitung menggunakan perkiraan tangkapan maksimum untuk berbagai jenis ikan. Perkiraan menangkap berkelanjutan dikonversi menjadi setara massa produksi primer berdasarkan pada berbagai spesies ikan. Nili tapak ekologi lahan perikanan di Pulau Lombok dihitung berdasarkan pada produksi primer yang diperlukan untuk mendukung ikan yang ditangkap. Produksi lahan perikanan ini dibagi menjadi perikana darat (tangkap, budidaya, kolam) dan perikanan laut yang ada di Pulau Lombok. Tapak ekologi lahan terbangun di Pulau Lombok dihitung berdasarkan luas lahan yang ditutupi oleh infrastruktur manusia baik transportasi, perumahan maupun industri.

Diasumsikan bahwa lahan terbangun menempati apa yang sebelumnya terdapat pada lahan pertanian, karena pemukiman manusia umumnya terletak di daerah yang sangat subur. Untuk mendapatkan nilai tapak ekologi lahan terbangun dibutuhkan data tentang jumlah rumah tangga, jumlah populasi dan standar kebutuhan lahan per orang/penduduk.

Tapak karbon dihitung berdasarkan daya serap karbon dioksida dikalikan dengan luas lahan hutan sebagai salah satu tutupan lahan yang berfungsi sebagai penyerap karbon, terutama karbon dari hasil pembakaran bahan bakar fosil, atau produk limbah. Disisi permintaan, Jejak karbon dihitung sebagai jumlah hutan yang dibutuhkan untuk menyerap emisi karbon dioksida pada atmosfer dari pembakaran bahan bakar fosil, perubahan penggunaan lahan (deforestasi, misalnya), dan emisi dari transportasi.

\section{HASIL DAN PEMBAHASAN}

Perhitungan tapak ekologi dihitung berdasarkan konsumsi tanaman pertanian, konsumsi kayu, konsumsi ikan baik laut maupun darat, konsumai daging dan luas ruang terbangun serta ruang penyerap karbon. Konsumsi untuk ruang penyerap karbon dihitung 
berdasarkan jenis tutupan lahan yang ada di wilayah di Pulau Lombok. Pertama sekali dilakukan adalah mengindentifikasi semua item konsumsi populasi baik barang maupun jasa. Selanjutnya dilakukan perhitungan terhadap nilai faktor panen setiap komoditas yang ada pada setiap kategori lahan terutama pada lahan pertanian, sedangkan untuk kategori lahan penyerapan karbon hanya dihitung daya serap karbon setiap kategori tutupan lahan. Perhitungan nilai Tapak Ekologi di Pulau Lombok dapat dilihat pada Tabel 3.

Tabel 3. Perhitungan Tapak Ekologi Pulau Lombok

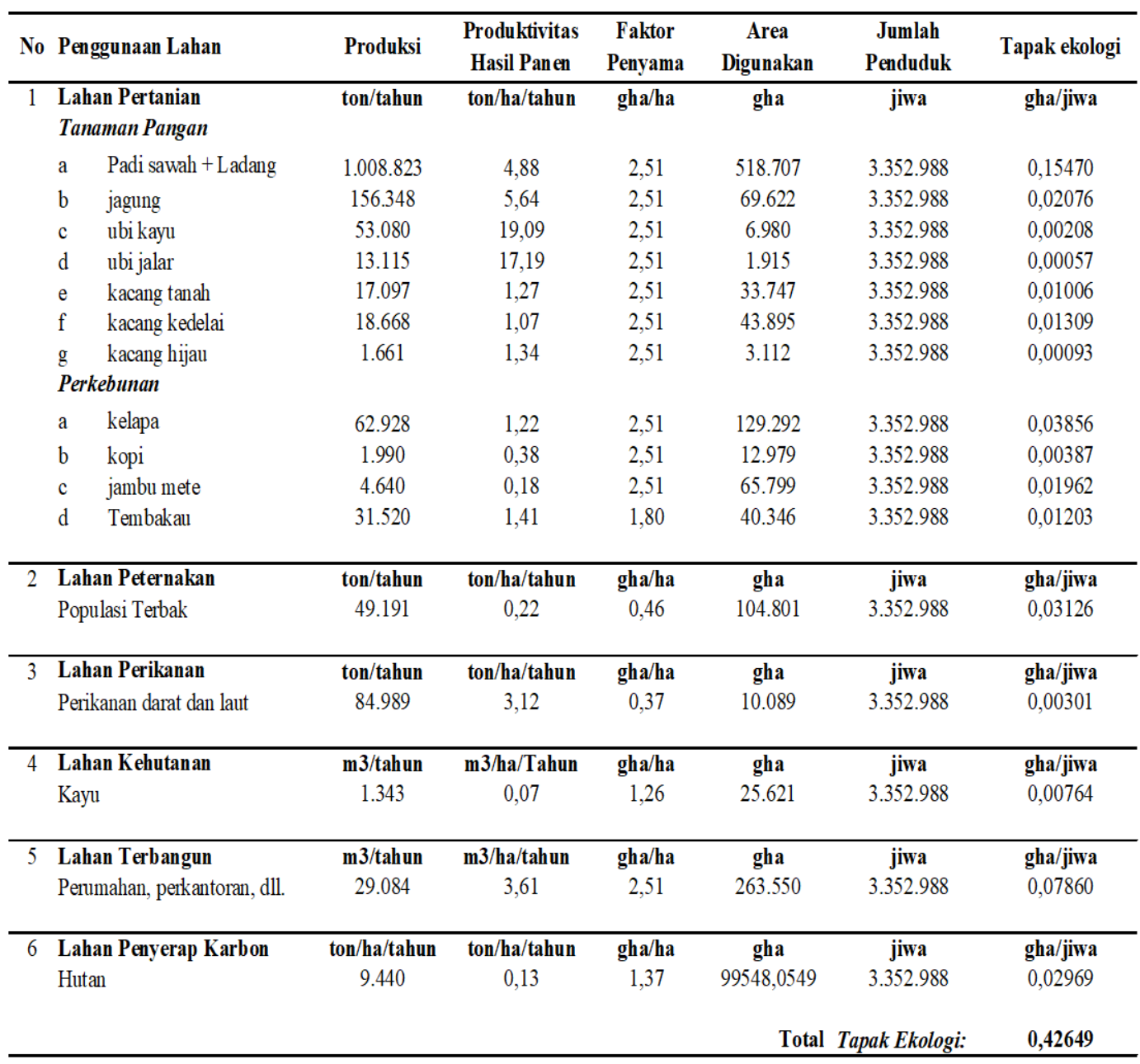

Hasil perhitungan nilai tapak ekologi menunjukkan bahwa total jumlah permintaan sumberdaya diberbagai jenis penggunaan ruang adalah sebesar 0,42649 gha/jiwa. Permintaan sumberdaya paling tinggi di wilayah Pulau lombok berada pada kategori penggunaan lahan pertanian sebesar 0,27629 gha. Sedangkan perhitungan nilai biokapasitasnya diketahui bahwa ketersediaan sumberdaya yang ada di Pulau Lombok sebesar 0,44627 gha. Pasokan sumberdaya yang paling tinggi tersedia pada kategori penggunaan lahan pertanian sebesar 0,27433 gha (Tabel 4). 
Tabel 4. Perhitungan Biokapasitas Pulau Lombok

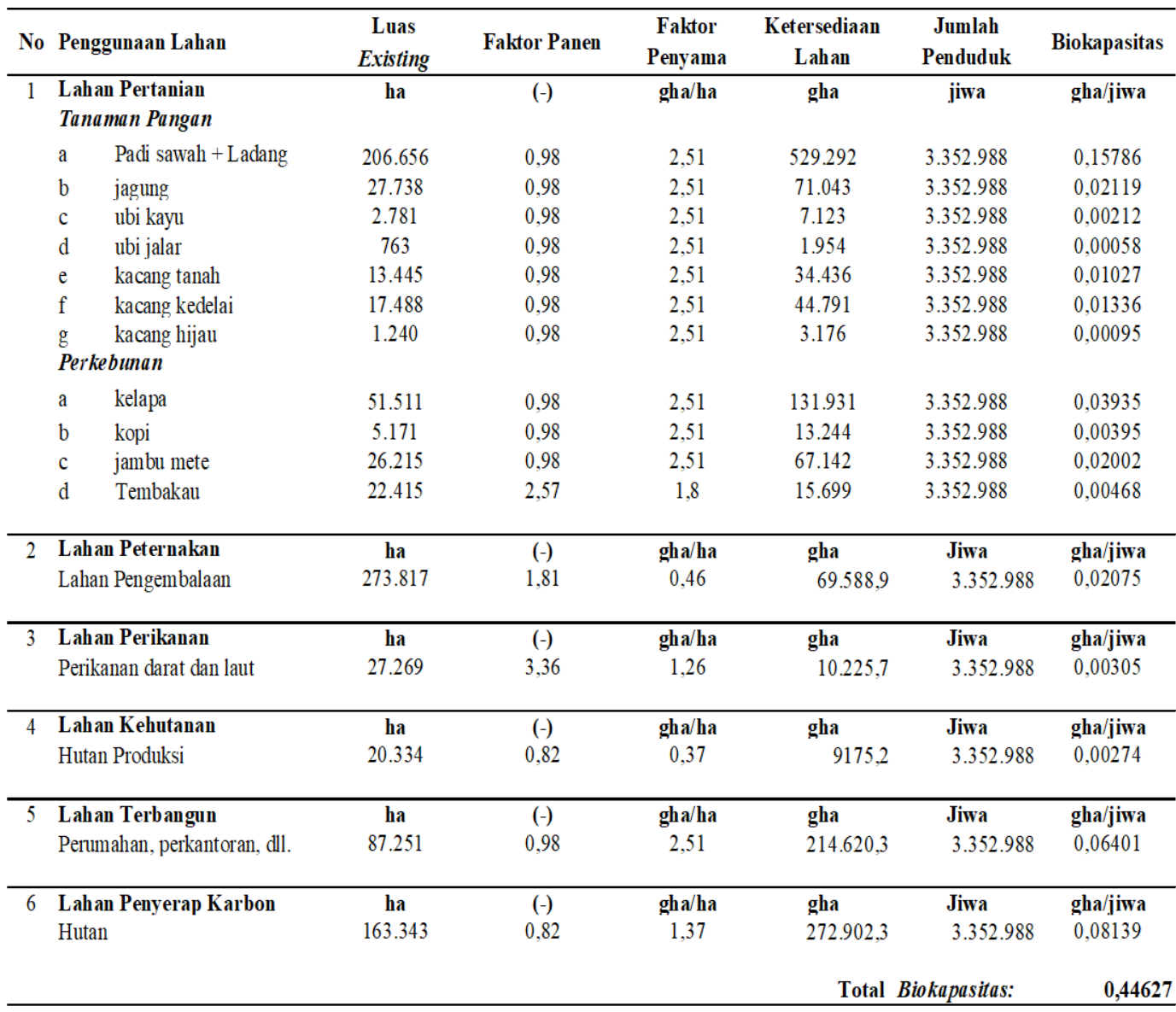

Perhitungan tapak ekologi dan biokapasitas mengasilkan nilai keseimbangan ekologi sebesar 0,01978 gha. Hal ini menunjukkan bahwa secara keseluruhan Pulau Lombok berada pada kategori Wilayah Surplus sumberdaya. Kondisi lahan perikanan dan penyerap karbon relatif masih aman meskipun pada lahan penyerap karbon dapat dilihat permintaan cenderung tinggi namun jumlah pasokan masih mampu untuk memenuhi permintaan sumberdaya.

Kondisi lahan pertanian, peternakan, kehutanan dan lahan terbangun berada dalam kondisi defisit dimana jumlah biokapasitasnya tidak mampu mengimbangi tingginya jumlah tapak ekologi. Berdasarkan hasil analisis dan pengamatan, besarnya jumlah permintaan akan lahan pertanian, peternakan, kehutanan serta lahan terbangun tidak lepas dari pengaruh; 1) tingginya permintaan akan lahan pertanian, 2) adanya pengaruh konversi lahan sawah menyebabkan lahan pertanian semakin berkurang sehingga mengalami defisit, 3) tingginya permintaan masyarakat akan konsumsi daging sebagai kebutuhan primer 4) tingginya permintaan kayu untuk kebutuhan papan, 5) meningkatnya jumlah penduduk sehingga kebutuhan akan lahan terbangun juga bertambah, 6) keberadaan jenis tutupan lahan dan 7) tingginya penggunaan bahan bakar minyak (energi) diberbagai kegiatan yang menyebabkan permintaan daya serap karbon juga semakin bertambah (Tabel 5). 
Tabel 5. Keseimbangan Ekologi Kategori Lahan Pulau Lombok

\begin{tabular}{lcccc}
\hline \multicolumn{1}{c}{ Penggunaan Lahan } & Tapak Ekologi & Biokapasitas & $\begin{array}{c}\text { Neraca } \\
\text { Ekologi }\end{array}$ & Kategori \\
\hline Lahan Pertanian & 0,27629 & 0,27433 & $-0,00196$ & Defisit \\
Lahan Peternakan & 0,03126 & 0,02075 & $-0,01050$ & Defisit \\
Lahan Perikanan & 0,00301 & 0,00305 & 0,00004 & Surplus \\
Lahan Kehutanan & 0,00764 & 0,00274 & $-0,00490$ & Defisit \\
Lahan Terbangun & 0,07860 & 0,06401 & $-0,01459$ & Defisit \\
Lahan Penyerap Karbon & 0,02969 & 0,08139 & 0,05170 & Surplus \\
\hline Total & $\mathbf{0 , 4 2 6 4 9}$ & $\mathbf{0 , 4 4 6 2 7}$ & $\mathbf{0 , 0 1 9 7 8}$ & SURPLUS \\
\hline
\end{tabular}

Tingginya permintaan akan sumberdaya lahan pertanian baik mencakup lahan yang dapat diusahakan (arable land) dan lahan yang tidak diusahakan (cultivated land) memiliki nilai permintaan yang cenderung tinggi. Melihat nilai pasokan dan permintaan yang ada, hal ini menandakan bahwa hingga saat ini lahan pertanian masih menjadi tumpuan utama sistem produksi dalam memenuhi konsumsi sumberdaya masyarakat di Pulau Lombok yang dominan bermata pencaharian sebagai petani. Tingginya nilai permintaan dipengaruhi oleh tingginya permintaan akan lahan pertanian yang terkonversi untuk berbagai penggunaan lain seperti tempat tinggal maupun kegiatan industri. Konversi lahan pertanian terjadi akibat adanya persaingan dalam pemanfaatan lahan antara sektor pertanian dan sektor non pertanian (Gambar 3). Persaingan terhadap pemanfaatan lahan tersebut muncul akibat adanya tiga fenomena ekonomi dan sosial yaitu keterbatasan sumber daya lahan, pertambahan penduduk danpertumbuhan ekonomi (Irawan 2008).

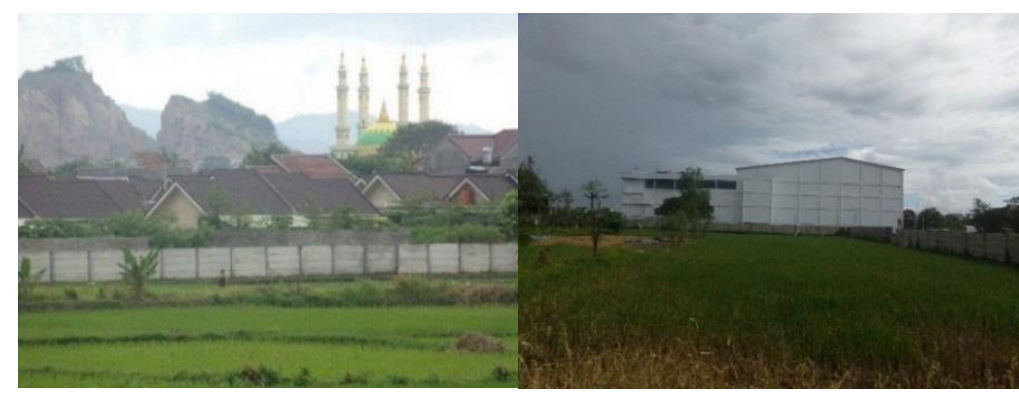

(a)

(b)

Gambar 3. Lahan pertanian yang terkonversi menjadi lahan terbangun dan industri (a) Lombok Barat, (b) Kota Mataram.

Kategori lahan peternakan juga mengalami defisit, hal ini dapat saja disebabkan oleh permasalahan tingginya tingkat konsumsi daging di masyarakat sedangkan jumlah produksi serta luas lahan pengembalaan semakin berkurang. Lahan terbangun memiliki nilai defisit ekologi paling tinggi diantara penggunaan lainnya. Dampak semakin meningkatnya laju pertumbuhan penduduk di Pulau Lombok menyebabkan kebutuhan lahan untuk lahan terbangun semakin meningkat. Semakin majunya pertumbuhan ekonomi wilayah juga menyebabkan semakin bertambahnya kebutuhan masyarakat akan lahan yang berfungsi sebagai tempat-tempat kegiatan industri, pertokoan serta perkantoran yang mendukung kegiatan ekonomi masyarakat. 
Nilai tapak ekologi lahan perikanan dan lahan penyerapan karbon mengalami surplus, hal ini berarti jumlah pasokan masih mampu memenuhi jumlah permintaan yang ada. Berdasarkan hasil pengamatan di lapangan, kategori lahan perikanan yang ada di Pulau Lombok memiliki beberapa permasalahan yaitu perusakan terumbu karang dan penangkapan ikan di laut dengan menggunakan bahan peledak serta racun. Fenomena ini masih marak terjadi disekitar wilayah administrasi Pulau Lombok dan pulau-pulau kecil yang mengelilinginya. Penggunaan bahan peledak dan racun mengancam kelestarian terumbu karang dan ikan, termasuk kelangsungan hidup para nelayan tradisional yang menangkap ikan dengan menggunakan pancing. Perusakan terumbu karang juga terjadi oleh aktivitas buang jangkar kapal yang dilakukan dengan sembarangan. Oleh karena itu, perlu ada koordinasi yang solid antar instansi pemerintah terutama pihak keamanan laut, dinas perhubungan laut, dinas kelautan dan lingkungan hidup, dinas pariwisata dan instansi lainnya untuk bersama-sama menangani permasalahan ini (Saufi et al. 2015).

Meningkatnya laju pertumbuhan penduduk juga dapat memicu terjadinya konversi lahan yang dapat berimplikasi pada penurunan kemampuan produksi suatu penggunaan lahan. Menurut Widiatmaka et al. (2013) salah satu penyebab konversi lahan yang berimplikasi pada menurunnya kemampuan produksi tersebut diantaranya adalah peningkatan kebutuhan akan pemukiman akibat pertumbuhan penduduk,meningkatnya kebutuhan akan lahan non-pertanian untuk sektor industri dan jasa, dan tentu saja meningkatnya prasarana dan infrastruktur yang menyertainya. Pembangunan pemukiman dan kawasan-kawasan terbangun biasanya berkaitan dengan pengembangan pusat pertumbuhan, dan selalu diikuti pula oleh meningkatnya prasarana infrastruktur, diantaranya jalan.

Untuk kategori lahan hutan, pasokan sumberdaya pada ruang penyerap karbon berbanding terbalik dimana jumlah pasokan mengalami defisit untuk mampu memenuhi jumlah permintaannya yang ada. Tingginya permintaan akan produksi hasil hutan untuk berbagai kebutuhan papan masyarakat mempengaruhi nilai tapak ekologi lahan hutan yang dapat merubahnya menjadi lahan yang bernilai defisit. Penebangan pohon di kawasan hutan lindung Gunung Rinjani dan area konservasi lainnya yang dilakukan oleh masyarakat baik dengan tujuan penebangan liar maupun pembukaan lahan baru untuk berkebun telah menjadi ancaman serius bagi kelestarian flora dan fauna di kawasan tersebut.

Permasalahan lain yang dapat terjadi adalah fenomena penggundulan hutan seringkali memicu terjadinya banjir bandang dan longsor di kaki Gunung Rinjani sebelah timur seperti daerah Sembalun dan Sambelia. Penangkapan, perburuan, dan komersialisasi binatang-binatang endemik Lombok yang langka dan dilindungi dilakukan secara liar dan tidak terkendali. Binatang binatang seperti monyet, penyu, dan berbagai jenis ikan langka diburu untuk dikonsumsi dan dijadikan peliharaan. Begitu juga dengan nasib hampir semua jenis burung di Lombok yang diburu untuk dikonsumsi dan dikomersilkan. Perdagangan ilegal burung di daerah ini sudah mencapai tingkat yang mengkhawatirkan sehingga apabila tidak segera dihentikan dan ditangani dengan baik dikhawatirkan akan menimbulkan ketidakseimbangan ekosistem dan petaka lingkungan dalam beberapa tahun mendatang (Saufi et al. 2015). 
Meskipun secara keseluruhan kondisi tapak ekologi Pulau Lombok masih dalam kondisi surplus namun perlu diwaspadai bahwa permintaan sumberdaya pada ketegori penggunaan lahan kehutanan, lahan terbangun dan lahan penyerap karbon dapat menjadi faktor paling dominan dalam menyumbang defisit ekologi di Pulau Lombok. Kegiatan oven tembakau di Pulau Lombok dapat menambah semakin tingginya gas-gas buangan yang harus diserap. Kebutuhan akan kayu bakar untuk kegiatan oven tembakau sebanyak 16.375 unit di Provinsi Nusa Tenggara Barat sangat besar. Hal ini penyebab terjadinya eksploitasi terhadap sumberdaya hutan di Pulau Lombok sehingga kelestarian hutan semakin terancam dan terjadi adalah penurunan debit mata air bahkan sampai hilangnnya mata air. Penurunan Debit mata air tersebut disebabkan oleh berkurangnnya kawasan lindung atau daerah resapan air akibat Illegal logging dan alih fungsi lahan yang mengakibatkan terjadinya lahan kritis dan menurunnya kualitas daerah resapan air (DisHut NTB 2009).

Tingginya permintaan kayu pada lahan hutan akan berpengaruh kepada semakin tingginya permintaan akan lahan penyerap karbon. Tingginya penggunaan bahan bakar yang menghasilkan gas buangan yang berlebih (polusi) maupun yang lainnya seperti penebangan hutan, pembersihan lahan, fermentasi produk peternakan, proses industri, sampah, pertambangan dan sebagainya (Rusli et al. 2009) akan mempengaruhi luas lahan hutan dan lahan penyerapan karbon. Akibat emisi $\mathrm{CO}_{2}$ (karbondioksida) dan gas-gas lainnya seperti sulfurdioksida, nitrogenoksida, nitrogendioksida, metan, kloroflourokarbon di atmosfer dapat mempengaruhi kenaikan konsentrasi gas rumah kaca. Kenaikan konsentrasi gas rumah kaca disebabkan oleh terjadinya peningkatan pelepasan atau emisi gas-gas tersebut seiring dengan peningkatan berbagai jenis pembakaran bahan bakar minyak (BBM), batu bara, dan bahan-bahan organik lainnya di permukaan bumi, penggunaan bahan-bahan tertentu seperti pupuk urea, dan dekomposisi atau pelapukan bahan organik (Dariah et al. 2009). Contoh kegiatan yang dapat meningkatkan konsentrasi gas rumah kaca yang ada di Pulau Lombok dapat dilihat pada Gambar 4.

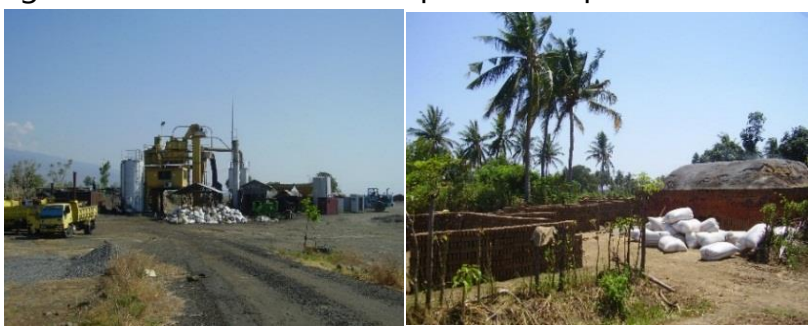

(a)

(b)

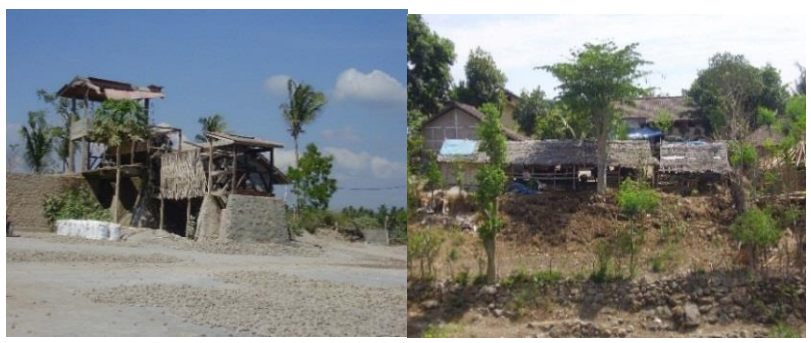

(c)

(d)

Gambar 4. Kegiatan yang dapat meningkatkan konsentrasi gas rumah kaca (a) Kecamatan Pringgabaya (b) di Kecamatan Peringgabaya, (c) Kecamatan Ijobalit, (d) Kecamatan Suela. 


\section{SIMPULAN}

Perhitungan nilai tapak ekologi mengasilkan nilai keseimbangan ekologi sebesar 0,01978 gha. Hal ini menunjukkan bahwa secara keseluruhan Pulau Lombok berada pada kategori wilayah surplus sumberdaya. Kondisi lahan perikanan dan penyerap karbon relatif aman meskipun pada lahan penyerap karbon nilai tapak ekologinya cenderung tinggi namun jumlah biokapasitas yang ada masih mampu memenuhi permintaan sumberdaya. Sedangkan kondisi lahan pertanian, peternakan, kehutanan dan lahan terbangun berada dalam kondisi defisit dimana jumlah biokapasitasnya tidak mampu mengimbangi tingginya jumlah tapak ekologi.

Diharapkan kepada pemerintah yang berwenang untuk selalu melakukan pembaharauan data setiap lima tahun mengenai seberapa besar nilai dan bagaimana kategori tapak ekologi Pulau Lombok guna mendapatkan kondisi tapak ekologi yang ideal. Pembaharuan data mengenai tapak ekologi ini diharapkan dapat menjadi kontrol dalam mengendalikan tingginya jumlah permintaan akan sumberdaya yang ada di wilayah Pulau Lombok. Selain itu hasil perhitungan nilai tapak ekologi ini juga dapat digunakan sebagai bahan pertimbangan dalam menyusun rencana tata ruang wilayah sehingga dapat diwujudkan pemanfaatan ruang yang tepat guna dan berhasil guna.

\section{UCAPAN TERIMA KASIH}

Penulis mengucapkan terima kasih kepada berbagai pihak yang telah membantu dalam proses pengumpulan data sekunder, pengamatan lapangan, serta analisis data sehingga penulisan artikel ini dapat terselesaikan dengan baik.

\section{DAFTAR PUSTAKA}

BPS NTB. 2015. Nusa Tenggara Barat Dalam Angka. Mataram: Badan Pusat Statistik Provinsi Nusa Tenggara Barat.

Dariah, A., Susanti, E., dan Agus F. 2009. Simpanan Karbon Dan Emisi CO2 Pada Lahan Gambut. Prosiding Balai Besar Penelitian dan Pengembangan Sumberdaya Lahan Pertanian.

Dinas Kehutanan Provinsi Nusa Tenggara Barat. 2009. Rancana Kehutanan Spasial 2009/2013. Mataram: DisHut.

Direktorat Jendral Penataan Ruang. 2010. Telapak Ekologis di Indonesia. Jakarta: Kementrian Pekerjaan Umum.

Ewing, B., Moore, D., Goldfinger, S., Oursler, A., Reed, A., Wackernagel, M. 2010. Ecological Footprint Atlas. United States of America (USA): Global Footprint Network.

Irawan, B. 2005. Konversi lahan sawah: Potensi Dampak, Pola Pemanfaatannya, dan Faktor Determinan. Jurnal Penelitian Agro Ekonomi. 23: 1-18.

Irawan B. 2008. Meningkatkan Efektifitas Kebijakan Konversi Lahan. Forum Penelitian Agro Ekonomi. 26 (2): 116-131.

Munibah, K., Sitorus, SRP., Rustiadi, E., Gandasasmita, K., Hartrisari. 2009. Model Hubungan Antara Jumlah Penduduk Dengan Luas Lahan Pertanian dan Permukiman (studi kasus DAS Cidanau, Provinsi Banten). Jurnal Tanah dan Lingkungan. 11 (1): 32-40.

Pasandaran, E. 2006. Alternatif Kebijakan Pengendalian Konversi Lahan Sawah Beririgasi di Indonesia. Jurnal Penelitian dan Pengembangan Pertanian. 25 (4): 123-129. 
Rusli, S., Septri, W., Hana, I. 2009. Tekanan Penduduk, Overshoot Ekologi Pulau Jawa, dan Masa Pemulihannya. Jurnal Transdisiplin Sosiologi, Komunikasi, dan Ekologi Manusia. 3 (1).

Saufi, A., Teguh, F., Ristanto, H., Basuki, P., Oehms, O., Vitriani, D., Creutz, L., Nuzullay, H. 2015. Rencana Induk Pariwisata Berkelanjutan Pulau Lombok 2015-2019. Badan Perencanaan dan Pembangunan Provinsi Nusa Tenggara Barat.

Wackernagel, M. 2005. National Footprint and Biocapacity Accounts:The underlying calculation method. California: Gobal Footprint Network.

Widiatmaka., Ambarwulan, W., Munibah, K., Santoso, BK. 2013. Analisis Perubahan Penggunaan Lahan dan Kesesuaian Lahan Untuk Sawah Di Sepanjang Jalur Jalan Tol Jakarta-Cikampek dan Jalan Nasional Pantura, Kab. Karawang. ProsidingSeminar Nasional\&Forum IImiah TahunanIkatan Surveyor Indonesia (FIT-ISI) 2013. Yogyakarta. Indonesia. 